\title{
JEJARING GRADUASI PADA TEKS EVALUATIF DI MEDIA SOSIAL FACEBOOK: ANALISIS GRADUASI- FORCE INTENSIFIKASI
}

\author{
Ziyaul Haq ${ }^{1}$, FX. Rahyono ${ }^{2}$, Untung Yuwono ${ }^{3}$ \\ Departmen Linguistik, Fakultas Ilmu Budaya, Universitas Indonesia, Depok 16424, Indonesia \\ 1yaulelite@gmail.com,2fxrahyono@gmail.com,3untungy@gmail.com
}

\begin{abstract}
Abstrak
Dalam sistem appraisal, aspek graduasi berkaitan dengan derajat makna evaluasi di dalam sebuah teks. Dengan sarana graduasi, pengguna Facebook dapat meyakinkan atau memicu reaksi pembaca terhadap pesan yang diunggah. Pada beberapa penelitian terdahulu, aspek graduasi lebih cenderung dilihat pada penggunaan elemen-elemen gramatikal yang berfungsi sebagai kata intensifier, penanda komparatif/superlatif, atau modalitas berdasarkan pada hubungan modifier dan modified pada tataran kata dan frasa saja. Pada artikel ini, penulis berupaya untuk melihat peran elemen-elemen gramatikal lainnya yang dapat berfungsi sebagai intensifikator dan melihat jejaring graduasi pada tataran tataran klausa hingga pada tataran wacana. Artikel ini diharapkan dapat memberikan gambaran yang lebih luas tentang aspek graduasi dalam jaring wacana.
\end{abstract}

Kata Kunci: Facebook, Appraisal, Graduasi, Attitude, Pragmatik.

\begin{abstract}
In the appraisal system, the graduation aspect relates to the degree of evaluation in a text. With graduation, Facebook users can reassure or trigger the readers' reactions to the uploaded message. In some previous research studies, the graduation aspect was more likely to be seen in the use of grammatical elements that function as intensifiers, comparative/superlative markers, or modalities based on modifier and modified relationships in word or phrase level. In this article, the author attempts to look at the role of other grammatical elements that can serve as intensifying and see the graduation network from the clauses level to the discourse level. This article is expected to provide a broader picture of the graduation aspects in the web of discourse
\end{abstract}

Keywords: Facebook, Appraisal, Graduation, Attitude, Pragmatic.

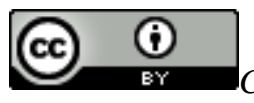

Creative Commons Attribution 4.0 International (CC BY 4.0)

\section{PENDAHULUAN}

Di dalam Facebook, setiap pengguna dapat mengekspresikan pikiran dan emosinya terhadap suatu hal (Junaedi, 2020). Umumnya, ekspresi diri yang ditunjukkan pengguna diharapkan dapat memicu respon atau mempengaruhi keyakinan atau pikiran pembaca. Hal demikian karena tindakan komunikasi bukan hanya tentang transmisi pesan, tapi juga tindakan mempengaruhi kognitif dan emosi partisipan lainnya untuk 
mencapai kesepahaman (Florea, Stepan, \& Puiescu, 2017; Junaedi, 2020; Lopato, 2016; Rahyono, 2012). Untuk mendapatkan respon pembaca, pengguna menggunakan berbagai strategi tertentu. Dalam sistim appraisal, hal ini berkaitan dengan aspek graduasi. Dalam sistem appraisal, graduasi berkaitan dengan aspek yang menjelaskan tentang derajat penilaian di dalam sebuah teks (Martin, JR., \& Rose, 2003; Martin. JR \& White, 2005). Graduasi dapat dilihat pada penggunaan intensifier, comparative dan superlative morphonlogy, repetition, graphonolgical dan phonological features ( Martin. JR \& White, 2005)

Dalam sistim appraisal, graduasi terdiri dari dua kategori, yaitu focus dan force. Namun, dalam artikel penelitian ini, pembahasan terkait graduasi hanya berkaitan dengan kategori. Graduasi force terdiri dari proses intensifikasi dan kuantifikasi. Graduasi forceintensifikasi berkaitan derajat kualitas objek yang dinilai, sedangkan graduasi forcekuantifikasi berkaitan dengan kuantitas sebuah objek yang dinilai (Martin. JR \& White, 2005). Adapun artikel ini hanya fokus pada aspek graduasi jenis force-intensifikasi. Graduasi force-intensifikasi terdiri dari proses isolating, maximitation, lexicalisation, infusion, repetition, dan metafora. Pada proses isolating, proses graduasi ditandai dengan penggunaan intensifier seperti kata 'greatly' pada kalimat 'This upsets me greatly'. Kata intensifier berfungsi menguatkan makna kata yang berangkaian dengan kata tersebut. Pada proses maximisation, proses graduasi ditandai dengan penggunaan intensifier yang menandung skala makna tertinggi (maksimal) seperti pada kata utterly, totally, completely, dan sebagainya. Pada proses lexicalization, proses graduasi intensifikasi ditandai dengan penggunaan leksikal yang dapat berfungsi sebagai kualitas (ajektiva) seperti kata 'ice' pada frasa 'ice cold'. Kata 'ice' di sini bersifat metaforis yang bermakna 'cold like a ice'.(Martin. JR \& White, 2005)

Adapun pada proses infusion dan metafora, proses graduasi dilihat berdasarkan derajat makna yang dikandung di dalam item leksikal itu sendiri. Pada proses infusi, proses graduasi dilihat berdasarkan derajat makna di dalam kata itu sendiri. Misalnya, derajat makna kata 'joyous' lebih tinggi daripada makna 'happy'. Pada proses metafora, proses graduasi dilihat berdasarkan pada derajat makna kata yang bermakna metaforis. Misalnya, untuk menggambarkan kondisi yang meningkat (improvement), verba 'skyrocketed' yang berfungsi sebagai metafora lebih tinggi dari derajat makna improve (meningkat). Adapun pada proses repetition, proses graduasi dilihat berdasarkan efek retoris. Proses repetisi dapat dilihat berdasarkan pengulangan bentuk kata dan pengulangan makna semantis.

Aspek-aspek graduasi telah banyak disinggung di dalam beberapa penelitian appraisal terdahulu. Swear ( 2015) menggunakan sarana graduasi untuk melihat upaya ahli medis meyakinkan laporan hasil lab kepada pasien. Penanda graduasi yang ditemukan seperti pada kata adverbia 'clearly', “somewhat, fairly, very, dan modalitas usuality', 'occasionally'; dan penanda comparative dan superlative. Crystalia dan Sunardi ( 2018) mengidentifikasi sarana graduasi pada penilaian seorang pengulas film "The Texas Chainsaw Massacre". Pada bagian analisis graduasi, peneliti menemukan penggunaan jenis graduasi negative force-down-scale sebanyak $72 \%$. Hal ini menunjukkan bahwa pengulas film tersebut cenderung menyatakan penilaiannya secara negatif dengan menggunakan strategi 'down-scale'. Adapun Putri ( 2019) mengidentifikasi sarana graduasi pada penilaian media massa terhadap sebuah peristiwa di dalam Bali Post dan Tribun Bali. Penanda graduasi dapat dilihat pada kata menghabisi, dirampas, dipukul, dan saking. 
Fan ( 2019) mengidentifikasi sarana graduasi di dalam pidato politik. Dalam penelitiannya, penutur menggunakan fitur graduasi force untuk memengaruhi audiens agar yakin dengan pesan yang disampaikan. Graduasi force dapat dilihat pada kata yang bermakna kuantifikasi seperti 'billion', 'multiple' dan kata yang bermakna intensifikasi seperti pada kata 'the best' dan 'vital'( menunjukkan makna 'important' atau 'significant'). Li ( 2019) mengidentifikasi sarana graduasi di dalam pidato "Conssesion Addressee" calon presiden USA. Dalam penelitian tersebut ditemukan penanda graduasi untuk meyakinkan audiens seperti kata 'large'; dan frasa month after month. Adapun dari segi intensifikasi, proses graduasi dapat dilihat pada proses penghalusan makna seperti pada frasa a little bit dan proses raising seperti pada kata completely, really, dan deeply, dan repetisi seperti pada ungkapan I so wish, I so wish.

Secara konseptual, pada penelitian terdahulu dan deskripsi aspek graduasi yang telah dijelaskan oleh Martin dan White (Martin. JR \& White, 2005), menunjukkan bahwa proses graduasi beroperasi pada tataran frasa dan klausa. Proses graduasi dilihat pada tiga aspek: (1) hubungan antar elemen gramatikal; (2) derajat makna item leksikal; (3) efek retoris dengan menggunakan repetition. Di dalam Martin and White (Martin. JR \& White, 2005), proses graduasi berdasarkan hubungan antar elemen gramatikal dilihat pada proses isolation, maximisation, dan lexicalisation. Di dalam proses tersebut, elemen yang berfungsi sebagai intensifikator berfungsi sebagai modifier bagi elemen yang terintensifikasi. Misalnya, adverbia 'greatly' pada ungkapan 'This upsets me greatly' mengintensifikasi makna verba 'upsets'.

Secara leksikogramatikal, berdasarkan pada contoh kasus aspek graduasi di dalam sebuah teks yang disajikan oleh Martin dan White ( 2005) dan beberapa penelitian terdahulu (Crystalia \& Sunardi, 2018; Fan, 2019; Li, 2019; Putri, 2019; Swear, 2015), elemen-elemen intensifikator terdiri dari elemen sirkumstansi (intensifier), epitet (noun atau adjective), dan elemen modalitas pada tataran frasa. Proses graduasi pada tataran frasa tersebut menunjukkan kombinasi endosentrik. Kombinasi endosentrik menunjukkan hubungan antara elemen modifier dan modified (D. Alan Cruse, 2004; D A Cruse, 1995). Dalam hubungan endosentrik, elemen modifier (kata penjelas) memperluas makna elemen modified-nya (kata inti) (D. Alan Cruse, 2004; Hasan, 2003; Pateda, 2010). Misalnya, elemen sirkumstansi (adverbia) greatly berfungsi sebagai modifier yang memperluas makna elemen proses (verba) upsets dan nomina ice befungsi sebagai modifier yang memperluas makna adjektive cold. Dengan kata lain, elemen intensifikator merupakan elemen yang berfungsi sebagai modifier.

Dalam struktur gramatikal, setiap elemen gramatikal masing-masing membawa makna dan fungsi gramatikal untuk membangun sebuah makna berdasarkan pada relasi gramatikal antar elemen, baik dalam tataran frasa, klausa, kalimat, dan hingga wacana (D A Cruse, 1995; Eggins, 2004; Martin, JR., \& Rose, 2003; Rahyono, 2012). Dalam perspektif Systemic Fungsional Linguistic, elemen gramatikal tersebut dapat disebut sebagai unsur-unsur transivitas yang terdiri dari jenis-jenis proses, elemen partisipan, dan elemen sirkumstansi yang saling terhubung satu sama lain dalam sistem transivitas (Eggins, 2004; Halliday et al., 2014). Berdasarkan hubungan gramatikal tersebut, masingmasing elemen gramatikal memiliki peran dan fungsi dalam proses pemaknaan di dalam wacana. Dengan demikian, dalam proses graduasi, berdasarkan fungsi gramatikalnya, masing-masing elemen-elemen gramatikal memiliki potensi untuk berfungsi sebagai elemen intensifikator terhadap elemen gramatikal lainnya. Oleh karena itu, elemen intensifikator tidak hanya dilihat pada elemen sirkumstansi (intensifier), epitet (noun atau adjective), dan modalitas. 
Dalam wacana, proses pemaknaan berdasarkan hubungan gramatikal tidak hanya terjadi pada tataran frasa (modifier-modified), tapi juga pada tataran klausa hingga wacana berdasarkan pada hubungan logis antar elemen gramatikalnya. Di dalam kalimat kompleks, klausa pengembang atau anak kalimat memperluas makna kalimat induk. Hubungan logis tersebut terdiri dari hubungan adisi, komparasi, waktu, dan konsekuensi (Martin, JR., \& Rose, 2003; Wiratno, 2018). Dengan demikian, berdasarkan hubungan antar elemen-elemen gramatikal tersebut, proses graduasi juga dapat terjadi pada tataran yang lebih luas, yaitu klausa, kalimat, hingga wacana. Klausa pengembang berpotensi untuk menguatkan makna yang dinyatakan di dlaam klausa inti.

Adapun proses graduasi berdasarkan pada skala makna seperti pada temuan penelitian terdahulu dan kasus graduasi yang dipaparkan Martin dan White juga masih dilihat pada skala makna sebuah item leksikal seperti pada kata 'menghabisi' dan 'dirampas' yang menggambarkan tindakan kejahatan; kata 'joyous' yang menggambarkan sebuah suasana "bahagia" berkaitan dengan aspek implikatur. Dalam hal ini, implikatur mengacu pada sebuah proposisi yang mengimpikasikan proposisi lain: proposisi P meliputi atau mengimplikasikan proposisi Q (A. Cruse, 2011; D. Alan Cruse, 2004; Levinson, 1987). Aspek implikatur tidak hanya mengacu pada relasi logis (makna semantik), tapi juga relasi kontekstual (makna pragmatik) (Cutting, 2005; Grice, 1975; Paltridge, 2012; Saeed, 2011).Oleh karena itu, sebuah kata dapat mengandung informasiinformasi tertentu secara logis (entailement) ataupun secara kontekstual (pragmatik) yang dapat menguatkan makna kata tersebut. Aspek implikatur tidak hanya terjadi pada satuan leksikal saja, tapi juga dapat dilihat pada kalimat hingga wacana. Dengan kata lain, proses graduasi yang melibatkan aspek implikatur juga dapat beroperasi pada seluruh tataran struktur gramatikal. Sebuah frasa, klausa atau kalimat hingga rangkaian kalimat dalam satu bangun wacana dapat mengimplikasikan sebuah informasi-informasi tertentu yang dapat menguatkan makna teks tersebut.

Adapun proses graduasi dengan menggunakan proses repetition dilihat berdasarkan efek retoris di dalam wacana. Efek retoris dengan proses pengulangan merupakan upaya untuk menegaskan makna, menarik perhatian pembaca, atau menunjukkan suatu hal yang penting (Wales, 2014). Mengacu pada efek retoris, penguatan sebuah makna pesan juga dapat dilihat pada exclamation dan ironi (Arifin, E.Zaenal \& Tasai \& Tasai, 2006; Black, 2006; Colston, 2015; Finoza, 2005; Zhukovska, 2010). Dari segi makna, efek retoris juga sangat berkaitan dengan aspek kontekstual atau aspek pramatik (Black, 2006). Dengan kata lain, penggunaan efek retoris tersebut juga melibatkan aspek implikatur. Dalam bahasa Inggris, excalamation ditandai dengan penggunaan $\mathrm{W}$-H element yang berfungsi sebagai intensifikator elemen yang berangkaian dengannya seperti pada kalimat "what a great writer..", "how amazing he was" menunjukkan sebuah makna yang kuat (Eggins, 2004). Adapun dalam bahasa Indonesia, excalamation ditandai dengan penggunaan kata 'alangkah' seperti pada kalimat 'alangkah besarnya pesawat itu' (Arifin, E.Zaenal \& Tasai \& Tasai, 2006; Finoza, 2005). Ungkapan eksklamasi tersebut mengimplikasikan sebuah objek memilki nilai yang kuat sehingga menimbulkan kekaguman penuturnya. Ironi disebut sebagai bentuk wacana yang bersifat mencemooh atau ekspresi ketidaksukaan yang lebih besar melalui kontradiksi makna atau penyimpangan norma teks (Black, 2006). Secara semantik, tuturan ironi terlihat sopan (positif), tapi secara implisit maknanya tidak sopan (negatif) (Leech, 2014). Misalnya, kalimat "you're a fine friend!" secara ironi dapat bermakna "you're so bad friend!". Hal ini juga mengimplikasikan sebuah hal yang sangat buruk pada objek yang dinilai. 
Pada artikel penelitian ini, penelitian ini bertujuan untuk melihat jaringan graduasi pada tataran yang lebih luas, yaitu kalimat dan wacana. Berdasarkan hubungan gramatikal antar elemen, penelitian ini bertujuan mengidentifikasi elemen-elemen gramatikal lainnya yang dapat berfungsi sebagai intensificator terhadap elemen lainnya, apakah ditinjau secara semantik atau pragmatik. Selain itu, penelitian ini juga ingin melihat efekefek retoris lainnya yang dapat mengoperasikan proses graduasi di dalam teks. Penelitian ini hanya fokus pada aspek graduasi force-intensification, yaitu proses graduasi yang berfokus pada kualitas seuatu objek yang dinilai.

\section{METODE PENELITIAN}

Pada artikel ini, teks evaluatif berasal dari dua akun fan pages, yaitu Kata Kita (KK) dan Mak Lambe Turah (MLT). Jumlah data yang diambil adalah sebanyak 50 teks status dari setiap akun facebook. Data bahasa pada dua akun Facebook tersebut dikodifikasi dalam bentuk penomoran berdasarkan nomor status dan nomor data tuturan penilaian. Penomoran data tersebut seperti berikut: data nomor 36-02 menunjukkan bahwa data tersebut berasal dari data status ke 36 dan data tuturan ke-01. Analisis graduasi force-intensifikasi pada kedua akun tersebut tersebut menggunakan pendekatan kualitatif dengan menggunakan metode deskriptif analisis. Dalam proses analisis graduasi, penulis menggunakan analisis appraisal (Martin. JR \& White, 2005) untuk menentukan kategori-kategori graduasi yang terdapat di dalam teks dan analisis Systemic Functional Language (SFL)(Eggins, 2004; Halliday et al., 2014) untuk menentukan penanda graduasi berdasarkan pada elemen gramatikal di dalam teks. Di samping itu, data dianalisis secara semantik dan pragmatik (Huang, 2007; Renkema, 2004; Saeed, 2011). Analisis semantik untuk menemukan makna eksplisit dari data penelitian, sedangkan analisis pragmatik untuk mengidentifikasi makna implisit dari data penelitian.

\section{HASIL DAN PEMBAHASAN}

Pada bagian ini, penulis akan menyajikan analisis data penelitian dalam dua bagian, yaitu berdasarkan pada: (1) hubungan antar elemen gramatikal; dan (2) berdasarkan pada penggunaan efek retoris. Berikut adalah analisis jejaring graduasi pada kedua akun Facebook, Mak Lambe Turah (MLT), dan Kata Kita (KK):

\section{Hubungan antarelemen gramatikal: Hubungan antarelemen pada tataran klausa}

Tabel 1 Tabel analisis Graduasi pada Akun MLT Berdasarkan Hubungan Antarelemen Gramatikal

\begin{tabular}{|c|c|c|c|}
\hline Tuturan Penilaian & $\begin{array}{c}\text { Hubungan } \\
\text { antarelemen } \\
\text { Gramatikal }\end{array}$ & Intensifikator & Yang diintensifikasi \\
\hline $\begin{array}{l}\text { brutal itu bukan fiksi } \\
\text { [36-02] }\end{array}$ & carrier + atribut & bukan fiksi (atribut) & brutal (carrier) \\
\hline $\begin{array}{l}\text { gaberner sibuk jelong- } \\
\text { jelong keluar negeri } \\
\text { [37-01] }\end{array}$ & $\begin{array}{l}\text { Aktor + sirkumstansi- } \\
\text { proses }\end{array}$ & $\begin{array}{lr}\text { sibuk jelong-jelong } \\
\text { keluar } \\
\text { (sirkumstansi-proses) }\end{array}$ & gaberner (aktor) \\
\hline
\end{tabular}




\section{brutal itu bukan fiksi [36-02];}

Dari segi wacana kalimat 36-02 di atas mengacu pada status yang menggambarkan sebuah peristiwa intimidasi yang dilakukan oleh oknum kelompok terhadap ibu dan anak. Adapun pada kalimat 36-02, kata brutal (elemen carrier) mengacu pada perilaku intimidasi yang digambarkan di dalam status Facebook. Kata brutal (elemen carrier) menggambarkan bahwa perilaku intimidasi atau perundungan terhadap ibu dan anak tersebut sebagai perilaku yang jahat atau kejam. Berdasarkan pada aspek graduasi, makna kata brutal (elemen carrier) diintensifikasi oleh makna frasa bukan fiksi (elemen atribut). Hal ini menunjukkan bahwa tindakan perundungan tersebut merupakan peristiwa yang sungguh-sungguh menggambarkan perilaku yang kejam.

\section{gaberner sibuk jelong-jelong keluar negeri [37-01]}

Dari segi wacana, kalimat 37-01 berkaitan dengan kritik penutur terhadap gubernur yang dianggap memiliki kinerja yang buruk dalam mengatasi permasalahan di Tanah Abang. Kata 'gaberner' pada kalimat tersebut merupakan sebutan sang gubernur yang mengandung konotasi negatif, yaitu gubernur yang tidak benar atau tidak mampu menjalankan tugasnya. Berdasarkan aspek graduasi, makna kata 'gaberner' (elemen aktor) diintensifikasi oleh frasa verba 'sibuk jelong-jelong keluar negeri' (elemen sirkumstansi-proses). Frasa verba 'sibuk jelong-jelong keluar negeri' memberikan sebuah asumsi negatif, yaitu sebuah sikap meninggalkan tanggungjawab untuk bersenangsenang. Hal ini dapat menegaskan bahwa sang gubernur sungguh layak disebut sebagai "gaberner".

Tabel 2 Tabel analisis Graduasi pada Akun KK Berdasarkan Hubungan Antarelemen Gramatikal

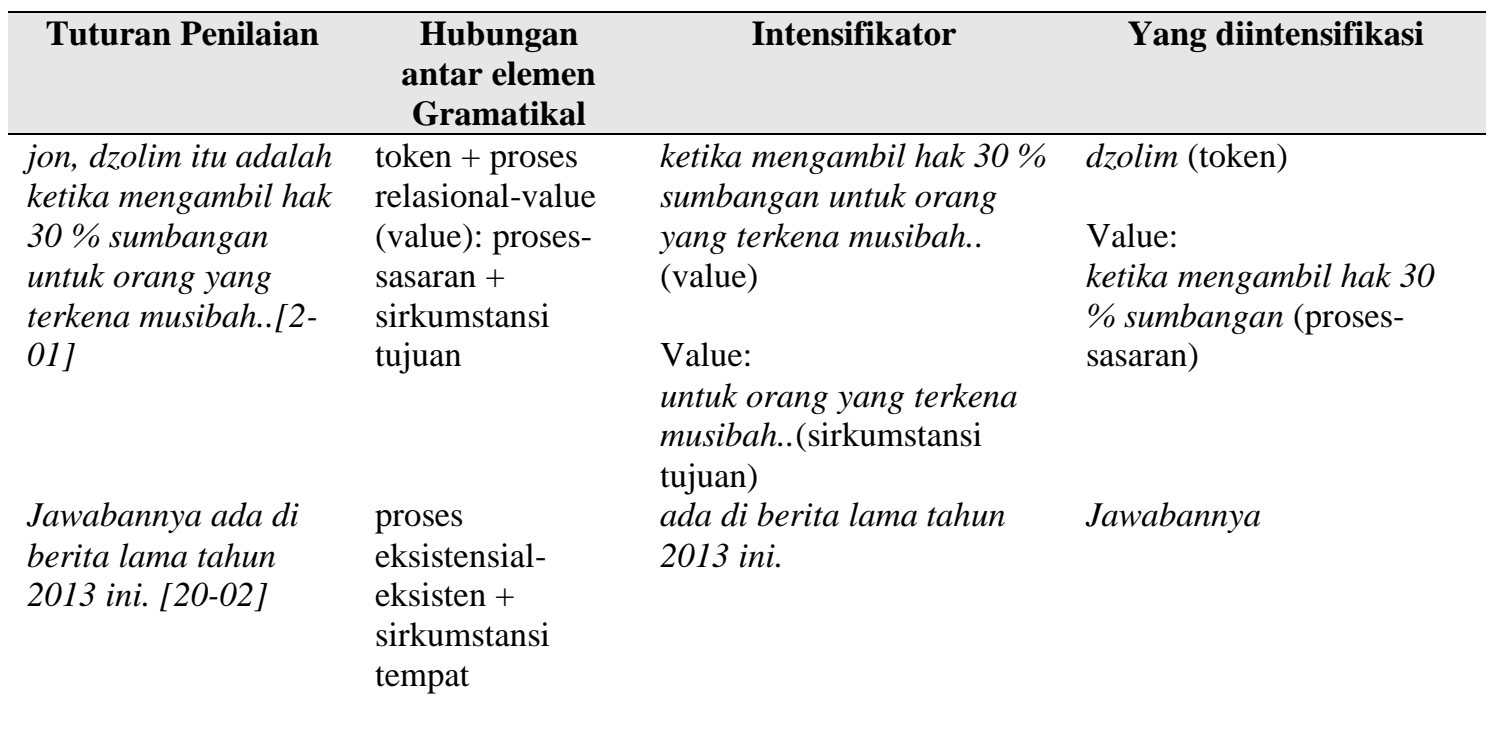


jon, dzolim itu adalah ketika mengambil hak $30 \%$ sumbangan untuk orang yang terkena musibah..[2-01]

Pada kalimat di atas, makna kata 'dzolim' (zalim) dapat mengacu pada sebuah perbuatan yang kejam tanpa belas kasihan. Dari segi graduasi, kenegatifan makna kata 'dzolim' (elemen token) diintensifikasi dengan frasa 'ketika mengambil hak $30 \%$ sumbangan untuk orang yang terkena musibah' (elemen value). Elemen value pada kalimat di atas mengelaborasi makna kata 'dzolim' atau dengan kata lain menegaskan bentuk kezaliman yang dilakukan oleh seseorang. Adapun pada elemen value pada kalimat di atas, proses graduasi nilai juga dapat dilihat pada frasa 'untuk orang yang terkena musibah' (elemen sirkumstansi tujuan) yang mengintensifikasi kenegatifan makna frasa mengambil hak $30 \%$ sumbangan (elemen prosesmaterial-sasaran). Dengan demikian, ungkapan mengambil hak $30 \%$ sumbangan untuk orang yang terkena musibah.. mengimplikasikan sebuah tindakan yang tidak adil dan tanpa rasa belas kasihan dengan mengambil hak orang yang sangat membutuhkan dana sumbangan tersebut. Adapun ungkapan tersebut juga dapat mengimplikasikan sebuah tindakan yang tidak amanah karena menunjukkan tindakan mengambil hak 30\% sumbangan.

\section{Jawabannya ada di berita lama tahun 2013 ini. [21-02]}

Berdasarkan pada wacana status Facebook, kalimat 21-02 di atas berkaitan dengan penggambaran penutur terhadap gerakan politik 2019 Ganti Presiden yang dianggap sangat berkaitan dengan tindakan dan kasus korupsi. Pada kalimat di atas, frasa 'jawabannya' (elemen eksisten) dari segi wacana mengacu pada kalimat "MENGAPA MEREKA NGOTOT 2019 GANTI PRESIDEN" [21-01]. Secara kontekstual, gerakan 2019 Ganti Presiden dianggap sebagai gerakan yang dipenuhi oleh tindakan intoleransi, ujaran kebencian terhadap pemerintah, dan kelompok diskriminasi. Dari segi graduasi, kenegatifan makna frasa 'Jawabannya' (elemen eksisten) diintensifikasi dengan frasa ada di berita lama tahun 2013 ini (elemen proses eksistensial - sirkumstansi tempat). Dari segi wacana frasa 'berita lama tahun 2013' mengacu pada pada kalimat judul berita yang dikutip penutur pada status tersebut "Sidang suap impor daging, jaksa: PKS cari dana 2 T untuk pemilu.." [21-05]. Dapat dikatakan bahwa gagasan pada kalimat judul berita tersebut mengandung makna negatif. Dengan demikian, hal ini menunjukkan bahwa tindakan "ngotot" yang ditunjukkan oleh kelompok gerakan 2019 Ganti Presiden tersebut sungguh sebuah tindakan yang sangat buruk karena didasari oleh tujuan untuk korupsi.

\section{Hubungan logis antarklausa}

Tabel 3 Data Bahasa Akun MLT Berdasarkan Hubungan logis Antarklausa

\begin{tabular}{|c|c|c|c|}
\hline Tuturan Penilaian & $\begin{array}{l}\text { Hubungan logis } \\
\text { antar Klausa }\end{array}$ & Intensifikator & Yang diintensifikasi \\
\hline $\begin{array}{l}\text { nih orang ngeselin } \\
\text { banget, udah divonis } \\
\text { belom juga } \\
\text { dikerangkeng.. [13-01] }\end{array}$ & $\begin{array}{l}\text { Hubungan sebab- } \\
\text { akibat }\end{array}$ & $\begin{array}{l}\text { udah divonis belom juga } \\
\text { dikerangkeng.. } \\
\text { (sebab) }\end{array}$ & $\begin{array}{l}\text { ngeselin banget } \\
\text { (akibat) }\end{array}$ \\
\hline
\end{tabular}


nih orang ngeselin banget, udah divonis belom juga dikerangkeng.. [13-01]

Dari segi wacana, kalimat 13-01 di atas berkaitan dengan kritik penutur terhadap proses hukum seorang terpidana yang belum diputuskan secara final. Frasa ngeselin banget pada klausa akibat menggambarkan sebuah ekspresi emosi negatif terhadap proses hukum tersebut. Adapun klausa sebab 'udah divonis belom juga dikerangkeng' mengimplikasikan sebuah ketidakberesan proses hukum tersebut. Ketidakberesan tersebut menggambarkan suatu hal yang memicu kemarahan orang-orang yang mengharapkan proses hukum berjalan sesuai yang mereka harapkan. Dari segi graduasi, klausa "sebab" tersebut menegaskan makna negatif dari ekspresi emosi pada frasa 'ngeselin banget'. Hal ini juga menunjukkan bahwa penutur sangat bersungguh-sungguh mengekspresikan kekesalannya.

Tabel 4 Data Bahasa Akun KK Berdasarkan Hubungan logis antarklausa

\begin{tabular}{|c|c|c|c|}
\hline Tuturan Penilaian & $\begin{array}{c}\text { Hubungan logis } \\
\text { antar Klausa }\end{array}$ & Intensifikator & Yang diintensifikasi \\
\hline $\begin{array}{l}\text { masa sampe segitunya } \\
\text { ngarep jabatan } \\
\text { sehingga harga diripun } \\
\text { dikesampingkan [1-02] } \\
\text { dzolim itu menipu } \\
\text { sudaramuslimnya } \\
\text { membakar hati mereka } \\
\text { agar ikutan membenci } \\
\text { saudara sebangsanya } \\
\text { dengan memicu isu } \\
\text { SARA... [2-04] }\end{array}$ & $\begin{array}{l}\text { Hubungan sebab- } \\
\text { akibat }\end{array}$ & 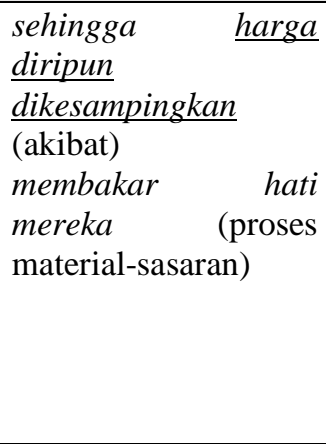 & $\begin{array}{l}\text { masa sampe segitunya } \\
\text { ngarep jabatan (sebab) }\end{array}$ \\
\hline
\end{tabular}

masa sampe segitunya ngarep jabatan sehingga harga diripun dikesampingkan [1-02]

Berdasarkan pada status, kalimat di atas berkaitan dengan sindiran penutur terhadap seorang politisi yang berupaya mengkampanyekan dirinya untuk ikut serta dalam pencalonan presiden di Pemilu 2019. Secara kontekstual, tindakan "ngarep jabatan" (mengharapkan jabatan) menggambarkan sebuah sikap ambisi yang dianggap untuk memenuhi kepentingan pribadi. Pada umumnya, tindakan tersebut dipandang secara negatif. Tindakan tersebut dipandang sangat lekat dengan sikap rakus, kelicikan, atau menghalalkan segala cara untuk meraih tujuannya. Dari segi graduasi, frasa 'harga diripun dikesampingkan' pada klausa akibat mengintensifikasi makna frasa 'ngarep jabatan pada klausa sebab. Frasa 'harga diripun dikesampingkan' pada klausa akibat menggambarkan sebuah tindakan yang tidak mementingkan rasa malu dengan melakukan hal yang dianggap negatif. Hal ini menegaskan bahwa tindakan 'ngarep jabatan' merupakan sebuah tindakan yang sangat buruk karena membuat harga diri atau rasa malu pada diri pelakunya sudah hilang.

dzolim itu ketika menyadari fitnah thdp ibu seorang Presidennya ketika ketahuan dan hanya klairifikasi basa basi minta maaf tapi kemudian hari mengulanginya lagi dan lagi... [2-03] 
Pada kalimat 2-04, kata 'fitnah' pada elemen value menunjukkan sebuah pernyataan bohong untuk menjelekkan seseorang. Pada umumnya, tindakan ini dipahami sebagai tindakan yang zalim dan merugikan citra diri seseorang akibat dari berita palsu tersebut. Secara graduasi, kenegatifan sikap yang digambarkan di dalam kalimat ini diintensifikasi dengan frasa 'dan hanya klarifikasi basa basi minta maaf' yang berfungsi sebagai elemen adisi yang menambah informasi pada kalimat tersebut. Hal ini menunjukkan bahwa perilaku orang yang melakukan "fitnah" tersebut sungguh menggambarkan orang yang sangat jahat karena dilakukan tanpa rasa penyesalan sama sekali.

\section{Hubungan logis antarkalimat}

MLT:

kalo beli kopi starbuck masuk neraka...sama aja pake fb juga masuk neraka karena Mark Julkipli ini kan mendukung LGBT. [14-01] setiap KLIK kita ke FACEBOOK itu bernilai duit loh, yg akan dibayarkan google ke FB. [14-06]

Kata starbuck pada kalimat 14-01 di atas mengacu pada merek kopi produk gerai retail asal Amerika. Berdasarkan pemberitaan di berbagai media, CEO Starbuck diberitakan mendukung keberadaan kelompok LGBT di Amerika. Dari segi wacana, kedua kalimat di atas berkaitan dengan sindiran dan kritik penutur terkait pernyataan pemuka agama yang menganggap bahwa membeli produk kopi "Starbuck" dapat masuk neraka karena turut menyumbang dana ke LGBT yang didukung oleh pemilik perusahan "Starbuck". Dari segi wacana, kedua kalimat tersebut menunjukkan hubungan logis elaboratif, yaitu kalimat 14-06 mengelaborasi gagasan kalimat 14-01. Dari segi pragmatik, kalimat 14-01 mengandung implikasi bahwa pemuka agama tersebut juga dapat masuk neraka karena ikut mendukung kelompok LGBT. Implikasi tersebut mengacu pada konteks faktual yang menunjukkan bahwa pemuka agama tersebut memanfaatkan Facebook sebagai sarana dakwah. Di samping itu, dalam pemberitaan media massa, CEO Facebok juga dikabarkan mendukung kehadiran kelompok LGBT. Adapun kalimat 14-01 menunjukkan hubungan perbandingan analogis, yaitu antara membeli kopi Stabuck dan menggunakan Facebook. Analogi tersebut menunjukkan bahwa apa yang pemuka agama tersebut lakukan juga termasuk ke dalam golongan orang yang dapat masuk neraka seperti yang ia sampaikan terkait membeli kopi Starbuck. Dari segi graduasi, implikasi ini diperkuat di dalam gagasan kalimat 14-06. Hal ini menunjukkan bahwa pemuka agama tersebut juga sungguh dapat digolongkan sebagai pendukung LGBT.

$K K$ :

berbagai kabel berantakan dan dibiarkan di pinggir jalan. [4-03] tidak ada pengawasan sama sekali. [4-04]

Kedua kalimat di atas, secara wacana menunjukkan hubungan elaboratif. Kalimat 4-04 mengelaborasi gagasan pada kalimat 4-03. Gagasan pada kalimat 4-03 dapat mengimplikasikan sebuah asumsi bahwa jajaran pemerintah daerah tidak memiliki kepedulian terhadap keindahan kota dengan membiarkan kabel bekas konstruksi berserakan di pinggir jalan. Hal ini dipertegas dengan gagasan pada kalimat 4-04 "tidak ada pengawasan sama sekali". Hal ini menguatkan asumsi yang dikandung di dalam 
kalimat 4-03 bahwa pemerintah daerah sungguh tidak dapat mengatur tata kota dengan baik dengan menjaga keindahan kotanya.

jon, dzolim itu adalah ketika mengambil hak $30 \%$ sumbangan untuk orang yang terkena musibah.. [2-01]

dzolim itu ketika membuat berita hoax tujuannya memancing benci pada pemimpin negerimu yang sah.. [2-02]

Dari segi wacana, kedua kalimat di atas menunjukkan hubungan adisi. Kalimat 202 berfungsi untuk menambahkan gambaran tentang tindakan "dzolim" yang dinyatakan pada kalimat 2-01. Dari segi graduasi, hal tersebut menunjukkan sebuah proses intensifikasi makna negatif tindakan "dzolim" tersebut dan juga meningkatkan penggambaran negatif pada subjek tindakannya. Hal tersebut memberikan gambaran bahwa subjek pelaku tindakan tersebut sangat sungguh jahat.

\section{Efek retoris:}

\section{Eksklamasi}

MLT:

\section{betapa tidak bercermin dikau? [1-01]}

Dari segi wacana, kalimat 1-02 di atas berkaitan dengan kritik penutur kepada seorang anggota Dewan yang mengkritik pemerintah terkait banyak kasus narkoba tanpa mengkritik rekannya sesama anggota dewan yang menjadi tersangka pengedar narkoba. Asumsi penutur ini dianggap sebagai sebuah tindakan "tidak bercermin" (tidak introspeksi diri). Secara retoris, kalimat eksklamasi di atas menggambarkan sebuah ekspresi emosi yang kuat dalam menggambarkan suatu hal. Secara graduasi, kalimat di atas menunjukkan sebuah proses intensifikasi untuk menggambarkan sikap "tidak bercemin”. Proses intensifikasi ini juga dapat dikategorikan ke dalam jenis maximisation.

\section{Repetisi}

MLT:

nih orang ngeselin banget, udah divonis belom juga dikerangkeng.. [13-01] sejak november 2017 sampe tahun baru, gong xi fscai, sampai maret, mau april, bentar lagi puasa, lebaran, coblosan, agustusan, natalan, tahun baru lagi..nih orang kapan eksekusinya? [13-04]

Berdasarkan pada aspek graduasi, kedua kalimat di atas menunjukkan sebuah proses repetisi dalam tataran wacana. Proses repetisi tersebut terjadi pada kata 'dikerangkeng' yang mengalami repetisi pada kalimat 13-01 pada penggunaan kata 'eksekusi'. Repetisi tersebut dapat dikatakan sebagai repetisi secara makna semantis. Kata 'dikerangkeng' dan 'eksekusi' sama-sama mengacu pada makna 'dipenjara'.

$K K$ :

masa sampe segitunya ngarep jabatan sehingga harga diripun dikesampingkan [1-02]

umumnya orang yang meminta minta jabatan tidak amanah, justru terkadang orang yang berdiam diri orang yang amanah atas jabatan yang diberikan dan diterimanya [1-03] 
Dari segi graduasi, ketiga rangkaian kalimat di atas menunjukkan proses repetisi pada tataran wacana. Frasa 'ngarep jabatan' mengalami repetisi pasa kalimat 1-03. Secara semantis, kedua frasa, 'ngarep jabatan' dan 'meminta-minta jabatan' menggambarkan sebuah keinginan untuk mendapatkan jabatan.

\section{Ironi}

MLT:

\section{luar biasa gubernur rasa presiden disambut oleh presden Erdogan [17-01]}

Dari segi wacana, kalimat 17-01 di atas mengacu pada sindiran penutur terhadap seorang gubernur yang dianggap tidak diperlakukan spesial oleh presiden Turki. Secara kontekstual, gagasan pada kalimat 17-01 di atas bertolak belakang dengan anggapan penutur bahwa gubernur tidak disambut oleh Presiden Erdogan, tapi sebaliknya gubernur sedang menunggu untuk menyambut kedatangan Presiden Erdogan bersama masyarakat sekitar di area masjid. Oleh karena itu, kalimat di atas dapat berbunyi dengan makna yang sebaliknya, yaitu_ "luar biasa gubernur rasa presiden tidak disambut oleh presden Erdogan". Dapat dikatakan bahwa ekspresi sindiran merupakan sebuah ekspresi yang menyatakan sebuah ketidaksukaan yang sangat besar. Dengan demikian, melalui sindiran, penutur berupaya menunjukkan bahwa penggambaran negatif terhadap gubernur. Penggambaran tersebut dapat memberikan beberapa asumsi bahwa anggapan tentang gubernur disambut oleh presiden tidak sesuai kenyataan; pemberitaan tersebut berupaya memberikan pencitraan yang palsu/ bohong tentang sang gubernur; gubernur tidak diperlakukan istimewa oleh presiden.

$K K$ :

\section{Gaberner (me)Rasa Presiden bisa ngerasain kecing di Los Angeles [2-03]}

Secara kontekstual, kata 'gaberner' dapat dimaknai "tidak benar" atau dengan kata lain "tidak layak menjadi gubernur". Dari segi graduasi, kenegatifan sebutan gaberner tersebut diintensifikasi dengan penggambaran pada frasa bisa ngerasain kecing di Los Angeles. Adapun frasa bisa ngerasain kecing di Los Angeles mengimplikasikan bahwa kunjungan kerja yang dilakukan gubernur di Los Angeles tidak membawa manfaat sama sekali. Hal ini menegaskan kenegatifan sebutan "gaberner" pada diri sang gubernur dan semakin menguatkan bahwa gubernur tidak mampu menjalankan tugasnya dengan baik dan tak layak jadi gubernur.

\section{SIMPULAN}

Berdasarkan analisis graduasi pada dua data penelitian di atas, dapat dilihat bahwa proses graduasi di dalam teks evaluatif tidak hanya terjadi di dalam hubungan gramatikal antar elemen pada tataran kata dan frasa, tapi juga dapat terjadi pada tataran kalimat hingga wacana. Di samping itu, selain elemen-elemen gramatikal seperti elemen sikumstansi (ditandai dengan adverbia), epitet (ditandai dengan ajektiva atau nomina), dan modalitas (modal adjunct), terdapat elemen-elemen gramatikal lainnya dapat berfungsi sebagai elemen intensifikator seperti elemen atribut, proses, dan jenis-jenis sirkumstansi jika ditinjau berdasarkan pada makna semantis dan pragmatisnya dalam wacana.

Pada artikel penelitian ini, dapat ditemukan batasan penelitian. Oleh karena itu, untuk penelitian selanjutnya, aspek graduasi masih sangat memungkinkan untuk diidentifikasi pada ragam jenis data. Selain dari hasil temuan pada penelitian ini, dapat dikatakan beberapa elemenelemen gramatikal juga masih memungkinkan berfungsi sebagai elemen inftensifikator. 


\section{DAFTAR PUSTAKA}

Arifin, E. Z., \& Tasai, S. A. (2006). Cermat berbahasa Indonesia. $8^{\text {th }}$ ed. Jakarta: Akademika Pressindo.

Black, E. (2006). Pragmatic stylistics. Edinburgh University Press.

Colston, H. L. (2015). Using figurative language. Cambridge University Press.

Cruse, A. (2011). Meaning in language: An introduction to semantics and pragmatics.

Cruse, D. A. (2004). Meaning in Language: An Introduction to Semantics and Pragmatics. Oxford University Press..

Cruse, D. A. (1995). Lexical semantics. Cambridge university press.

Crystalia, E., \& Sunardi, S. (2018). Evaluative Language as Portrayed in The Texas Chainsaw Massacre Movie Review by Roger Ebert: An Appraisal Analysis. EStructural, 1(01), 58-69. https://doi.org/10.33633/es.v1i01.1817

Cutting, J. (2005). Pragmatics and discourse: A resource book for students. Routledge.

Eggins, S. (2004). An Introduction to Systemic Functional Linguistics. Cassell..

Fan, X. (2019). The Application of Graduation in Political Speech. Theory and Practice in Language Studies, 9(7), 796. https://doi.org/10.17507/tpls.0907.07

Finoza, L. (2005). Komposisi bahasa Indonesia: Untuk mahasiswa nonjurusan bahasa. Penerbit Diksi Insan Mulia.

Florea, S., \& Puiescu, M. (2017). Communication Ethics: The Sacredness of Communication. The Holistic Society: Multi-Disciplinary Perspectives, 300-310.

Grice, H. P. (1975). Logic and conversation. In Speech acts (pp. 41-58). Brill.

Halliday, M., Matthiessen, C. M. I. M., \& Matthiessen, C. (2014). An introduction to functional grammar. Routledge.

Hasan, A. (2003). Tata bahasa baku Indoneisa. Jakarta: Rineka Cipta.

Huang, Y. (2007). Pragmatics. Oxford University Press. .

Junaedi, F. (2020). Etika komunikasi di era siber.

Leech, G. N. (2014). The pragmatics of politeness. Oxford University Press, USA.

Levinson, S. C. (1987). Pragmatics. Cambridge University Press.

$\mathrm{Li}$, Q. (2019). An analysis of graduation resources in concession addresses. International $\begin{array}{lllll}\text { Journal of Language and Linguistics, } & \text { 7(3), } & 102 .\end{array}$ https://doi.org/10.11648/j.ijll.20190703.12

Lopato, M. S. (2016). Social media, love, and sartre's look of the other: Why online communication is not fulfilling. Philosophy and Technology, 29(3), 195-210. https://doi.org/10.1007/s13347-015-0207-x

Martin, JR., \& Rose, D. (2003). Working with discourse. Continuum.

Martin. JR \& White, P. R. R. (2005). The Language of evaluation: Appraisal in English. PALGRAVE MACMILLAN.

Paltridge, B. (2012). Discourse analysis: An introduction. Bloomsbury Publishing.

Pateda, M. (2010). Semantik leksikal (2nd ed.). Rineka Cipta.

Putri, I. A. S. (2019). Ranah graduation dalam sistem appraisal yang digunakan pada harian Bali Post dan Tribun Bali. Linguistika: Buletin Ilmiah Program Magister $\begin{array}{llll}\text { Linguistik Universitas } & \text { Udayana, } & \end{array}$ https://doi.org/10.24843/ling.2019.v26.i02.p05

Rahyono, F. (2012). Studi makna. Penaku.

Renkema, J. (2004). Introduction to discourse studies.

Saeed, J. I. (2011). Semantics (2nd ed.). Blackwell Publishing.

Swear, M. A. (2015). Graduation resources in medical case reports written by native and non-native medical writers. Advances in Language and Literary Studies, 6(3). 
https://doi.org/10.7575/aiac.alls.v.6n.3p.101

Wales, K. (2014). A dictionary of stylistics. Routledge.

Widdowson, H. G. (2011). Discourse analysis. Vol. 133. Oxford University Press Oxford.

Wiratno, T. (2018). Pengantar ringkas linguistik sistemik fungsional. Pustaka Pelajar. Zaimar, O. K. S., \& Harahap, A. B. (2015). Teori wacana. Jakarta: Penaku. Zhukovska, V. V. (2010). English stylistics: Fundamentals of theory and practice 